\title{
Hungarian Martyrs, Refugees, and the Politics of Anticommunism in Salazar's Portugal, 1956-1957
}

\section{Steven Jobbitt}

\begin{abstract}
This article summarizes the findings of Jobbitt's early research into the experiences of Hungarian migrants in Portugal after World War II, and the way in which the Hungarian Revolution and its suppression in 1956 was politicized by Prime Minister António de Oliveira Salazar's Estado Novo ['New State']. Recognizing the propagandistic value of the 1956 Revolution and the refugee crisis that it created, the Salazar government celebrated Hungary's freedom fighters as martyrs while simultaneously painting an idealized and simplistic picture of an honorable Christian nation locked in a fundamentally moral struggle against the civilizational threat posed by Soviet barbarism and communist terror. However, in attempting to align its own political and ideological message with the actions of Hungary's revolutionaries and the suffering of its refugees, the Salazar regime ran the very real risk of highlighting the numerous contradictions, shortcomings, and injustices that defined the Estado Novo. Ultimately the Salazar regime's propagandistic support of the Revolution betrayed the hypocrisy of an authoritarian, clerico-fascist state, one that was not only unwilling to accept Hungarian refugees on a long-term basis, but also guilty of suppressing its own people and its non-European colonial subjects. This is a correction to the original article. For information about the changes made please see the erratum http://dx.doi.org/10.5195/ahea.2017.274
\end{abstract}

Keywords: 1956 Hungarian Revolution, Hungarian refugees, martyrdom, Estado Novo, Portugal under Salazar

Biography: Steven Jobbitt is Assistant Professor of Eastern European History at Lakehead University. He specializes in modern Hungarian history and has published on the history of subjectivity and the history of Hungarian geography in the first half of the twentieth century. His book Fodor Ferenc Önéletirásai ['The Autobiographical Writings of Ferenc Fodor'], coedited with Róbert Györi, was published in summer 2016. His current research focuses on Hungarian imperialism in the Balkans at the beginning of the twentieth century, and on the history of the radical right in Hungary since 1989.

On December 6, 1956, Portugal's National Secretary for Information [Secretariado Nacional da Informação] hosted a one-day conference in Lisbon dedicated to the Hungarian Revolution and its martyrs. Initiated by the executive committee of Portugal's ruling party União Nacional ['National Union'], the conference celebrated the actions of "an entire people" [um povo inteiro] who rose up against their communist oppressors on October 23, 1956 and who 
Jobbitt, Steven. "Hungarian Martyrs, Refugees, and the Politics of Anticommunism in Salazar's Portugal, 19561957." Hungarian Cultural Studies. e-Journal of the American Hungarian Educators Association, Volume 9 (2016) DOI: $10.5195 /$ ahea.2016.263

subsequently paid dearly for their actions as the Soviets moved to crush the rebellion in early November. In a pamphlet prepared especially for the conference, the Portuguese journalist Ramiro Valadão wrote of the two weeks he spent on assignment in Austria amidst Hungarian refugees, highlighting the suffering of a "heroic" people who had "wanted to break free from the darkness that enveloped them" [um povo que heróicamente quis libertar-se das trevas em que o envolviam] (Valadão 1956: 6). Having sacrificed themselves in the face of communist tyranny and violence, Valadão argued that Hungary's martyrs were worthy of Portuguese praise, while those Hungarians who were forced to flee the country were worthy of the nation's pity and support. "A cry of protest must be raised in this blessed land of Portugal," he argued, "so that the sacrifices of so many are not in vain and that the glory of so many martyrs and heroes is not forgotten" [um brado de protesto se erga nesta bendita terra de Portugal...para que o sacrifício de tanta gente não tenha sido inútil e a glória de tanto martírio e heroísmo não fique coberta pela carapaça do esquecimento] (5-6). ${ }^{1}$

Valadão's pamphlet, and the conference it was prepared for, is indicative of the way in which the Portuguese state attempted to propagandize the Hungarian Revolution and the people who subsequently died fighting against the Soviets. Casting Hungarian revolutionaries as heroes and martyrs who bravely stood against the injustices and violence of communism and Soviet imperialism, Portuguese propagandists sought to articulate and expose the brutality and inhumanity of Soviet Bolshevism and communism more generally, while simultaneously inspiring the "good people" [boa gente] of Portugal with images and stories of a brave Christian people willing to die in defense of Western civilizational values. However, existing primary sources indicate that the Hungarian Revolution and the refugee crisis that followed in its wake were by no means unproblematic for the authoritarian regime of Prime Minister António de Oliveira Salazar. Beyond being unable, and perhaps even unwilling, to accept large numbers of Hungarian refugees into the country or its colonies, Portuguese authorities struggled to manage both the message of the Revolution and the protests and demonstrations that the Hungarian uprising and its suppression by Soviet forces provoked amongst the people of Portugal.

Making use of previously untapped Portuguese archival sources, this article focuses primarily on the different ways that the Hungarian story was mobilized by Portuguese propagandists in 1956 and 1957, and offers some preliminary thoughts not only on the meaning and scope of this propaganda, but also on the political and ideological tensions as well as the material contradictions that it exposed within the context of Salazar's Estado Novo ['New State']. Though more work remains to be done on this topic, a critical examination of the politicization of the Hungarian Revolution by the Salazar regime, coupled with an analysis of the way in which Hungarian refugees were perceived by Portuguese authorities in the months that followed, not only broadens our knowledge of the Hungarian refugee story, but also contributes to an understanding of the ways in which the Hungarian crisis was viewed and handled by other countries. In the end, what we are left with is a clearer picture of what transpired when Salazar's idealized and ultimately simplistic representation of the Revolution and its heroes and martyrs

\footnotetext{
${ }^{1}$ All translations of the Portuguese, Hungarian, French, and Spanish sources cited in this article are my own. I would like to thank Dr. Rafaela Jobbitt for checking my translations of the Portuguese and Spanish texts, and for her advice on translating some of the more difficult passages. Any errors of translation are of course mine.
} 
Jobbitt, Steven. "Hungarian Martyrs, Refugees, and the Politics of Anticommunism in Salazar's Portugal, 1956-

1957." Hungarian Cultural Studies. e-Journal of the American Hungarian Educators Association, Volume 9 (2016) DOI: $10.5195 /$ ahea.2016.263

came face to face both with the complex political and ideological reality of the event itself and the practical implications of a European-wide refugee crisis.

\section{Hungarians in Salazar's Portugal Prior to 1956}

By means of providing some context, it is worth pointing out that the Revolution of 1956 was not the first time that Hungarian nationals had sought asylum in Portugal for political reasons, nor was it the first instance in which Hungarian narratives of martyrdom and suffering resonated with - and on some level became useful to - the Salazar regime. No doubt the most notable Hungarian "refugee" in Portugal after World War II was the former regent Admiral Miklós Horthy who, after being arrested by the Gestapo and sent to Germany along with his family in $1944,{ }^{2}$ eventually found permanent refuge in December 1948 in Estoril, a riverside, "flower-starred" town just west of Lisbon on the right bank of the Tagus (Horthy 2000: 313). ${ }^{3}$ Supported by friends of the family, Horthy lived his life "in obscurity" in a rather modest villa with his wife and daughter-in-law, and according to Thomas Sakmyster, "made little attempt to play an active role in émigré politics" (383). ${ }^{4}$ His only desire, it seems, was to be able to return to Hungary "to spend his last days in his native land and be buried near his home in Kenderes" (383), but with the crushing of the Hungarian Revolution by Soviet forces in November 1956, this dream also died. As his daughter-in-law Ilona Edelsheim Gyulai indicated in a 2007 interview, "after [the failure of the Revolution] he retreated into himself and no longer really involved himself in anything" [utána magába fordult és már nem igazán foglalkozott semmivel] (RTL 2007).

Though he may have retreated from politics and society more generally in the last years of his life, Horthy not surprisingly viewed Salazar's Portugal through a familiar political and ideological lens. As Sakmyster notes, Horthy remained a staunch opponent of Bolshevism until his death in 1957, and for the most part continued to adhere to the views that had informed his politics throughout the interwar period (383). It is therefore not at all surprising to discover that Horthy, like other prominent figures on the European right, found refuge in Salazar's Portugal after World War II (on right-wing exiles in Portugal after the war see Sauerwein 1955). Horthy

\footnotetext{
${ }^{2}$ It is worth noting that in Germany Horthy and his wife were separated from their son Niki and were only reunited with him when they were released in 1946 (Sakmyster 1994: 382). See also the newly published memoirs of Horthy’s wife (Horthy Miklósné 2015).

${ }^{3}$ Very little has been written on Horthy's exile in Portugal. In his memoirs, Horthy himself only dedicates one short paragraph to this chapter of his life. For what has been written by scholars see Sakmyster 1994: 382-383, Gosztonyi 1973: 114, Gosztonyi 1992: 146-151, and Vajnai 1990: 36. See also the short interview conducted by RTL in 2007 with Horthy's daughter-in-law, Ilona Bowden (Edelsheim Gyulai Ilona), "Horthy menyének különös emlékei: A grófnő részletes beszámolója a kormányzó családjának számüzetéséről' ['The Unusual Remembrances of Horthy's Daughter-in-Law: The Countess's Detailed Account of the Exile of the Regent's Family'], http://rtl.hu/rtlklub/hirek/hatter/cikkek/107077. See also her memoirs (Edelsheim Gyulai 2005).

${ }^{4}$ Horthy's lack of involvement in émigré politics in Portugal is confirmed in a memo written by the Head of Information Services [Direcção dos Serviços de Informação] in 1974. See Arquivo Nacional Torre do Tombo (ANTT), PIDE 1964-C1 (2).
} 
Jobbitt, Steven. "Hungarian Martyrs, Refugees, and the Politics of Anticommunism in Salazar's Portugal, 19561957." Hungarian Cultural Studies. e-Journal of the American Hungarian Educators Association, Volume 9 (2016) DOI: $10.5195 /$ ahea.2016.263

was especially appreciative of the "hospitality" that Salazar and the Portuguese people showed to him and his family, ${ }^{5}$ and noted at the end of his memoirs (first published in 1953) that he had been following "the rise" of Portugal under the "wise" leadership of Salazar "with utmost interest." He was certain, he wrote, that the nation was in good hands, and wished the country a "happy future to which the diligence of its lovable people entitles it" (Horthy 2000: 313). According to Júlio Sauerwein, who wrote briefly about his conversations with the former Hungarian Regent in his 1955 book Exiliados Régios no Estoril ['Exiled Royalty in Estoril'], Horthy had great respect for Salazar and the state he had built since coming to power as prime minister in 1932. Arguing that the Portuguese leader had been wrongfully labeled a "dictator" by enemies hostile both to him and to Portugal, Horthy defended the tactics Salazar used to realize his vision for the nation. "Indeed, if every dictatorship was like this," Horthy stated, "then of all the forms of government currently known, it would in truth be the best" [De ha minden diktatúra ilyen lenne, akkor a jelenleg ismert kormányformák közül a valóságban ez a legjobb] (Hungarian translation of the Portuguese original cited in Vajnai 1990: 36, see also RTL 2007).

Though Hungary and Portugal are rarely - if ever-examined in comparative historical context, the nature of Salazar's "clerico-fascist," corporatist-authoritarian regime displayed some important parallels with the neo-baroque order that the Hungarian right attempted to construct during the Horthy regency that lasted from 1920 to $1944 .{ }^{6}$ Like Horthy's Hungary, the Estado Novo ['New State'] proclaimed by Salazar in 1933 drew its support primarily from aristocrats, large landowners, the Catholic right, and the more conservative members of the bourgeoisie (see Gómez 2010, Raby 1988, Payne 1995: 312-317). It goes beyond the scope of this article to offer a detailed comparison of both regimes; however, it is worth pointing out that the corporatist constitution introduced by Salazar after he took power in 1932 shared much in common with the political policies and broader ideological goals of Horthy and his supporters between the wars. Amongst other measures, the constitution of the Estado Novo enhanced the power of financial-

\footnotetext{
${ }^{5}$ Horthy and his family (whose first choices for exile had actually been Italy or Switzerland) received no financial support from the Salazar government, but rather were dependent on a fund that was established by J.F. Montgomery, the former US Envoy to Hungary (1933-1941), and supported by a handful of donors. As Sakmyster writes, "two of the major contributors were Hungarian Jewish financiers who had survived the war and were living in the West" (383; see also Gosztonyi 1992: 148).

${ }^{6}$ I have chosen to use the label "clerico-fascist" to define Salazar's corporatist-authoritarian state. Not every historian would agree with my choice here. The Marxist historian Phil Mailer, for example, simply referred to the regime as "fascist" in his 1977 monograph (Mailer 1977), while the Portuguese historian Jorge Pais de Sousa describes the politics of the Estado Novo as fascismo catedrático ['professorial fascism'] (Pais de Sousa 2012). In Postwar, Tony Judt compares Salazar's Portugal to similar regimes in Spain and Greece, and argues that it was a "mix of censorious clericalism, corporate institutions and rural underdevelopment" (Judt 2005: 510-511). Stanley Payne, in turn, suggests that Salazar's Portugal does not fit a generic definition of fascism, and insists that the system imposed by Salazar should be viewed as "authoritarian corporatism" or even "authoritarian corporative liberalism.” (Payne 1995: 313) By comparison, D.L. Raby argues that "the Portuguese regime...exhibited several fundamental characteristics of fascism," and suggests that labels like "authoritarian" or "Iberian-corporatist" are too general and largely inaccurate. Raby concludes that the fascism of Salazar's Estado Novo, though it was "a weak, semi-peripheral fascism appropriate to the position of a weak, semi-peripheral country," nevertheless had "origins, functions, and structures that were qualitatively similar to those of other fascist regimes" (Raby 1988: 5-6, see also Solsten 1993 and Lewis 2002).
} 
Jobbitt, Steven. "Hungarian Martyrs, Refugees, and the Politics of Anticommunism in Salazar's Portugal, 19561957." Hungarian Cultural Studies. e-Journal of the American Hungarian Educators Association, Volume 9 (2016) DOI: $10.5195 /$ ahea.2016.263

colonial capital and the large landowners [latifundiários] while simultaneously limiting the influence of the radical (revolutionary) right, suppressing the political activities of the left, outlawing strikes, and replacing labor unions with national syndicates [sindicatos nacionais]. Though by no means identical, it is easy to understand why Horthy and his family felt very much at home in Portugal, and why the former Regent publically praised Salazar for his political and moral vision.

If there was much for Horthy to like in Portugal besides the weather and the beautiful scenery around Lisbon, there is little doubt that Salazar also found Horthy to be a sympathetic character, and beyond this would have seen important parallels between the perceived historical and civilizational "missions" of both nations. More research needs to be done on this question, but the primary sources suggest that the historical narrative disseminated internationally by the Horthy regime and its supporters was discussed by, and quite likely found an enthusiastic audience with, the upper echelons of Salazar's government. A copy of a 1943 memorandum forwarded by the Hungarian Legation in Lisbon to Portuguese officials is a good example of the language and political ideas that resonated with the elite of the Estado Novo. Written in Spanish, the document had originally been sent by the Hungarian Ambassador in Madrid to Spain's Minister of Foreign Affairs (the Conde de Jordana). Marked "strictement confidentiel," the ambassador began the memorandum by stating that the Hungarian government shared the Spanish minister's critical assessment of the war being waged by the great powers, one that was fueled (at least on the part of the Nazis and the Soviets, and perhaps also the Allies) by a desire to create a nueva ordenación ['new order'] in Europe (on the nature of this three-way political and ideological struggle in Europe in the 1930s and 1940s, see Mazower 2000). "We share your doubts," the ambassador wrote, "about the efficacy of the projects that each of the belligerentswho are themselves blinded by their passions - wish to impose on the defeated" [Comparte plenamente sus dudas con respecto a la eficacia de aquellos proyectos que, cualquiera de los beligerantes - cegados por las pasiones_desearía imponer al vencido]. Just like the Conde de Jordana, the Hungarian Ambassador was of the belief that a lasting and just peace in Europe could only be realized by nations like Spain which, devoid of "passion," acted "in complete knowledge of the responsibility it has been charged with by its great moral mission to maintain Western civilization" [en complete conocimiento de su responsibilidad, se harián cargo de aquella gran mission moral, que consiste en no dejar hundirse la civilización occidental]. ${ }^{7}$

Echoing sentiments that also resonated in Portugal during the war and under Salazar's leadership more generally, the Hungarian Ambassador stressed the idea that Hungary, as a conservative Christian-nationalist state, was key to the regional stability of Central Europe, and beyond this also to the survival and future rehabilitation of Western civilization after the war. Casting the nation as "a natural fortress" [una fortaleza natural] that, for a millennium, had

\footnotetext{
${ }^{7}$ Arquivo Nacional Torre do Tombo (ATTN), AOS/CO/NE-21, Pt. 14, "Correspondência sobre as seguintes questões: Política externa da Hungria" ['Correspondence Concerning the Following Questions: The Foreign Politics of Hungary'], "Copie de Mémorandum remis par le Ministre de Hongrie à Madrid au Comte Jordana le 26 mars 1943" ['Copy of the Memorandum sent by the Hungarian Ambassador in Madrid to Count Jordana on March 26, 1943'], 1 .
} 
Jobbitt, Steven. "Hungarian Martyrs, Refugees, and the Politics of Anticommunism in Salazar's Portugal, 19561957." Hungarian Cultural Studies. e-Journal of the American Hungarian Educators Association, Volume 9 (2016) DOI: $10.5195 /$ ahea.2016.263

raised the civilizational level of the region while simultaneously acting not only as a buffer between Latin, German, and Slavic interests, but also as a crucial cultural, political, and economic crossroads between West and East, the ambassador stated that Hungary's foreign policy was determined by two fundamental principles. One principle (already noted above) was that Hungary should continue to act as a "pillar of peace and order in Central Europe" [un pilar de la paz y del orden en Centro-Europa]. The second principle justified Hungary's military participation in the war by underscoring the importance of defending the sovereignty, and even the very existence, of Hungary itself. As the memorandum outlined: "Hungary fights against that which threatens its independence, liberty, juridical order, Christian culture, and honored traditions. It is for this reason that our nation has felt obligated to take up arms against Bolshevism" [Hungría lucha contra aquel que amenaza su independencia, libertad, orden jurídico, cultura Cristiana y sus valerosas tradiciones. Por este motivo se ha visto obligada a tomar las armas contra el bolchevismo]. ${ }^{8}$

In order to continue Hungary's historical and ultimately moral mission both as a mediator of conflicting cultural and political interests, and as a defender of Christian values and Western civilization, the Ambassador stressed the importance of revising the terms of Trianon, the infamous post-World War I treaty imposed on Hungary by the victorious powers. By redrawing Hungary's borders, the allies had violated Hungary's territorial integrity and had deprived the nation of a full two-thirds of its former land. Casting Hungary's dismemberment in terms of an imperialist aggression akin to that of both the Habsburgs and Ottomans in centuries past, the Ambassador stressed that Hungary once again found itself in the position to defend its thousandyear-old civilizational mission through blood sacrifice. "Hungary has fought for 24 years," he wrote, "against the injustice of Trianon, solely to survive. This struggle explains our entire politics...Hungary wants to live in peace in order to be able to play its role as mediator in Central Europe" [Hungría lucha desde hace 24 años contra la injusticia de Trianón, solamente para vivir. Esta lucha explica toda su política...Hungría quiere vivir en paz para poder desempeñar su gran papel de mediador en el centro de Europa]. Surrounded by hostile forces, Hungarians had no choice but to fight to reclaim what had been taken from them after World War I. As the Hungarian Ambassador concluded: "Divided we are unable to live; we have lost our soul" [Dividada es incapaz de vivir y pierde su alma]. ${ }^{9}$

The image and discourse of Hungarian martyrdom and suffering that defined the Horthy era to 1944 took on a new but nevertheless familiar meaning in émigré circles after 1948-1949 as Hungary, along with the rest of East Central Europe, came under Soviet control, and as the Rákosi regime subjected Hungarians to the hardships and terrors associated with the process of

${ }^{8}$ ATTN, AOS/CO/NE-21, Pt. 14, “Correspondência sobre as seguintes questões: Política externa da Hungria”" ['Correspondence Concerning the Following Questions: The Foreign Politics of Hungary'], “Copie de Mémorandum remis par le Ministre de Hongrie à Madrid au Comte Jordana le 26 mars 1943” ['Copy of the Memorandum sent by the Hungarian Ambassador in Madrid to Count Jordana on March 26, 1943’], 2.

${ }^{9}$ ATTN, AOS/CO/NE-21, Pt. 14, “Correspondência sobre as seguintes questões: Política externa da Hungria” ['Correspondence Concerning the Following Questions: The Foreign Politics of Hungary'], "Copie de Mémorandum remis par le Ministre de Hongrie à Madrid au Comte Jordana le 26 mars 1943” ['Copy of the Memorandum sent by the Hungarian Ambassador in Madrid to Count Jordana on March 26, 1943'], 3. 
Jobbitt, Steven. "Hungarian Martyrs, Refugees, and the Politics of Anticommunism in Salazar's Portugal, 19561957." Hungarian Cultural Studies. e-Journal of the American Hungarian Educators Association, Volume 9 (2016) DOI: $10.5195 /$ ahea.2016.263

Stalinization that his government had unleashed on the Hungarian people (for a nuanced treatment of this process in Hungary see Pittaway 2012). A pamphlet published in Portuguese in 1951 by the Conselho Nacional Húngaro ['Hungarian National Council'] provides a good indication of the anti-Soviet discourse that not only dominated political discussions within the Hungarian émigré community in Portugal and elsewhere after World War II, but also overlapped with the ideological position of the Salazar government (the Conselho Nacional Húngaro was very likely the Portuguese "branch" of the Magyar Bizottmány established in New York in 1948 and headed by Béla Varga, a Catholic priest and one-time Speaker of the Hungarian National Assembly from February 1946 to July 1947, see Gosztonyi 1992: 148). Working out of an office in Lisbon, the Hungarian National Council used the platform it had been granted by Portuguese authorities to denounce the crimes being committed at the time by Hungary's Stalinist regime, and in particular the mass deportations that had begun in the summer of 1951. Titled "Protestai Contra as Deportações em Massa dos Húngaros!' ['Protest Against the Mass Deportations of Hungarians!'], the pamphlet called upon the international community, and the United Nations more specifically, to bring an end to "these barbarous acts... [ones] that are being committed by a false government - a puppet regime that follows the inhuman terrorist orders of their Soviet overlords" [estes actos barbaros de deportação são cometidos por um governo falso-um regime fantoche que odedece às ordens desumanas e terroristas dos senhores soviéticos] (Conselho Nacional Húngaro 1951: 3). Arguing that the oppressive acts of the Hungarian government and their Soviet allies violated not only existing peace treaties but also the notion of human rights recently agreed upon by the United Nations, the authors of the pamphlet condemned the deportations as constituting "part of a malicious Soviet strategy," one based upon naked aggression and imperialism [essas deportações fazem parte da maldosa estratégia soviética de imperialism e de agressão] (3).

The idea that the Hungarian people were innocent victims of both imperialist aggression and an oppressive political system was central to the rhetoric employed by the Hungarian National Council in the pamphlet. "Since May 1951," the authors wrote, "50,000 Hungarians have been taken away from Budapest, not to mention other cities. These innocent victims of the Red Terror have been transported in cattle cars to unknown destinations. Many died during the trip. Many committed suicide" [Desde Maio de 1951, 50.000 húngaros foram afastados de Budapeste, para não falar de outras cidades. Estas vítimas inocentes do Terror Vermelho foram transportadas, em vagões de gado, para destinos desconhecidos. Muitas morreram durante a viagem. Muitas suicidaram-se] (2). Both the suffering of the deportees as well as the mode of transport to the camps were important points for the Hungarian National Council to underscore, not only because they suggested the innocence of those targeted by the regime, but also because they provided an opportunity to compare the actions of the communists to the crimes committed by the Nazis during World War II. Noting that, since May 1951, the "victims" of state oppression were no longer even accused of crimes, but were simply deemed "undesirable" by communist police [desde Maio deste ano que as vítimas deixaram de ser acusadas da práctica de crimes! À polícia communista basta classificá-las de 'indesejáveis'], the pamphlet claimed that the deportees "receive only 250 grams of bread per day" and that "they have no other food, no shelter, and nothing to wear." Stating that there was very little information on the fate of those caught up in these latest communist acts of terror, they wrote: "No one knows their destiny. We saw them last boarding trains for the slave camps situated in the Soviet Union" [Os deportados recebem, apenas, por dia, 250 gramas de pão. Não há outros alimentos. Não têm que vestir. 
Jobbitt, Steven. "Hungarian Martyrs, Refugees, and the Politics of Anticommunism in Salazar's Portugal, 19561957." Hungarian Cultural Studies. e-Journal of the American Hungarian Educators Association, Volume 9 (2016) DOI: $10.5195 /$ ahea.2016.263

Ninguém sabe do seu destino. Viram-nos, pela última vez, a caminho de campos de escravos, situados na União de Soviética] (2). Declaring that the tactics adopted by Stalinists were the same as those used by the Nazis, the Hungarian National Council denounced the deportations as an act of genocide. Citing the words of the New York-based Béla Varga, who visited Hungarian exiles in Portugal during a tour of Western Europe in 1951 (Gosztonyi 1992: 148), the pamphlet exclaimed: "What Stalin is doing to the people of Hungary surpasses the cruelty of Hitler. In the name of the innocent people who have been condemned to death, the relatives [of these innocents], who live in free countries, call upon the free people of the world to stop this genocide! [O que Estaline faz ao povo da Hungria ultrapassa a crueldade de Hitler. Em nome das pessoas inocentes, que foram condenadas à morte, os seus parentes, que vivem nos países livres, apelam para os povos livres do mundo. Acabem com este genocídio!] (1).

The extent to which the Portuguese government attempted to politicize and promote the work of the Hungarian National Council is not clear from the existing archival sources, but there can be no doubt that the protests of Hungarian exiles fell on sympathetic ears and ran parallel with the anticommunist propaganda being issued at the time by the Portuguese state. As a founding member of NATO, Portugal was a key player in the US-dominated alliance against the Soviet Union, and was committed geopolitically to halting the global spread of Bolshevism. At home, left-wing dissidence was an ever-present problem, and though the regime pursued domestic communists vigorously (especially in the late 1940s when it attempted to crush the Portuguese Communist Party (PCP) completely, see Raby 1988), revolutionary communism posed a consistent threat to the legitimacy and continued survival of the Salazar government. What happened in the global struggle against communism was therefore very relevant to Portuguese politics, and to the propaganda machine that in many ways was the heart and soul of Salazar's Estado Novo.

\section{Politicizing the Martyrs of the Hungarian Revolution}

Given the clerico-fascist ideology of the Salazar regime as well as its anti-Soviet stance geopolitically, the outbreak of the Hungarian Revolution on October 23, 1956 was an event that the Portuguese state could not easily overlook. Despite the fact that the Revolution itself ultimately exposed a number of internal contradictions of the Estado Novo (more on this below), on the surface the spontaneous uprising of the Hungarian people against a communist system imposed by Mátyás Rákosi and backed by the Soviets was politically useful, and served at least some of Salazar's propagandistic needs. When cast in simplistic terms as a revolt of the people against the injustices of communism and the tyranny of Soviet imperialism, the heroic actions of Hungarian revolutionaries proved useful both politically and ideologically to Portugal's authoritarian regime, and this for at least three interconnected reasons.

First and perhaps most obviously, the celebration of Hungary's heroes alongside a condemnation of the system they sought to overthrow could be framed strategically in an effort to further the state's anticommunist position. The oppression that had given rise to the Hungarian Revolution, coupled with the violence with which the uprising was crushed, provided the propagandists of Salazar's Estado Novo with concrete evidence that they could employ to convince the Portuguese people of the fundamental cruelty of the communist system. As the journalist Valadão made clear in his December 1956 pamphlet Hungria Martír ['Martyred Hungary'], the firsthand accounts he collected in Austria of Hungarians fleeing the violence in Budapest and other cities provided unique insight into the suffering and sacrifices of a people 
Jobbitt, Steven. "Hungarian Martyrs, Refugees, and the Politics of Anticommunism in Salazar's Portugal, 19561957." Hungarian Cultural Studies. e-Journal of the American Hungarian Educators Association, Volume 9 (2016) DOI: $10.5195 /$ ahea.2016.263

who, even if they were lucky enough "to find a bed to sleep in, or bread or heat," were nevertheless unable to escape the "constant nightmare" that defined their very existence under communism. "Each of the threats that weighed upon the Hungarian people," Valadão declared, whether it was "denunciation, prison, or deportation," were after all simply "different words describing the same fact: death" [Os que vivem na Hungria, se encontrarem a cama onde dormir ou pão e o aquecimento que lhes permita não morrer, não conseguem evitar o pesadelo constante provocado pelas ameaças que sobre eles pesam da delação, da prisão ou da deportação, que são, afinal, palavras diferentes para exprimir o mesmo facto: a morte] (6).

Situating himself in the "civilized" non-communist West, Valadão reflected on his two weeks in Vienna, noting that the city itself was "the last grand observation post that remained to the Occident" [o último grande posto observação que ao Ocidente resta]. From the Austrian capital, he wrote, it was possible "to contemplate the fantastic world" [contemplar esse mundo fantástico] that lay behind the Hungarian frontier (a border that was so close to Vienna that the city itself could be reached "in a mere hour or a few minutes by Soviet tanks and airplanes" [ $a$ uma escassa hora ou a muito poucos minutos dos tanques e da aviação soviéticos]) (7). Anyone who had previously doubted or downplayed the violence of the communist system or the ferocity of Soviet imperialism had only to consider the events in Hungary to be convinced otherwise. The evidence, he suggested, was overwhelming. As Valadão stated in no uncertain terms:

In the light of the blood of thousands of men, women, and children, it is possible to distinguish for the first time and with complete clarity the anguish and suffering of the world that has been closed off behind the Iron Curtain. In the face of the fire of this authentic apocalypse that has destroyed everything in its terrible wake, we hope people the world over have seen the bloody event for what it is (6).

[À luz do sangue de milhares de homens, de mulheres e de crianças, pôde distinguir-se, pela primeira vez com inteira nitidez, a angústia e o sofrimento do mundo sobre o qual se havia cerrado a 'cortina de ferro.' Face à fogueira de autêntico apocalipse que tudo abrasou em seu terrível incêndio, ousa-se esperar que os homens de todas as latitudes tenham visto o quadro sangrento e meditado no seu significado.]

In keeping with the anticommunist stance of Salazar's Estado Novo, Valadão underscored the "barbarism" of a system more or less imposed upon the innocent people of Hungary by its eastern neighbor, a system that spared no one, especially not women and children. Though not without a basis in fact, the message of Valadão's sometimes exaggerated and often inaccurate account of the events that had transpired in Hungary since October 23 was clear: Soviet imperialism was vicious, and communism was merciless. Highlighting the inhumanity and moral depravity of the occupying forces in Hungary, he informed his readers that "the soldiers have orders to fire on everyone, whether or not they are armed, and without regard to their age or sex" [os soldados têm ordem de fazer fogo sobre todo e qualquer ser humano, seja ou não possuidor de armas, tenha a idade ou o sexo que tiver] (21). Children, he claimed, were targets just like everyone else. As one purported example of Soviet cruelty, Valadão recounted (or perhaps even invented) the testimony of a Benedictine priest identified as Dr. Galambus [sic] 
Jobbitt, Steven. "Hungarian Martyrs, Refugees, and the Politics of Anticommunism in Salazar's Portugal, 1956-

1957." Hungarian Cultural Studies. e-Journal of the American Hungarian Educators Association, Volume 9 (2016) DOI: $10.5195 /$ ahea.2016.263

whose students were reportedly slaughtered in front of him in Györ. (The Benedictine priest in question here was undoubtedly Dr. Ireneus Galambos, who would later teach at the Burg Kastl Ungarisches Gymnasium in Kastl bei Amberg, Bavaria, that was established in 1958 for Hungarian refugee students; Galambos was named the director of the school in 1959.) As Galambus apparently testified:

The children formed a line in pairs with the priest in front. A Russian tank passed and, unleashing its horrific wrath, fired upon the fair-headed boys with its machine guns. The priest knelt begging for mercy and the tank continued on its path. Twenty children were killed and many others were wounded, some of them gravely (22).

[Vão as crianças formadas duas a duas com o sacerdote à frente. Passa um tanque russo que desfecha contra aquelas cabecitas loiras a fúria horrenda das suas metralhadoras. Ajoelha o padre a implorar a misericórdia divina e o tanque prossegue a sua marcha. Vinte crianças haviam morrido e muitas das outras estavam feridas, algumas das quais gravement.]

Dramatic as Valadão's account may have been, there is no evidence to suggest that such a massacre occurred at the Benedictine College in Győr (a city Valadão misidentifies as "Kraab," a misspelling of the city's German name Raab). Though the Benedictine College itself did exist, and was one of two Benedictine schools that continued to operate under communism (the other was in Pannonhalma, see Szalai 2012), the school was not attacked by Soviet tanks, despite what Valadão would have his readers believe. As the reflections of one former student of the Benedictine College suggest, no students were killed or wounded during the Revolution or its suppression. Though the steel tracks of the tanks could be heard "grinding in the streets" on the morning of November 4 [utcáin lánctalpas tankok csikorogtak], the city was spared the violence visited upon Budapest and other Hungarian cities by the Soviets (Fogarassy 2009). Having no doubt heard only second-hand stories about Dr. Galambus (who did indeed teach at the college), it appears Valadão either deliberately invented the story of a massacre of students in Györ orwhat is more likely_confused it with the October 26 massacre in nearby Mosonmagyaróvár of over fifty protesters (many of them students at the local agricultural university) by Hungarian State Security Police (ÁVH). ${ }^{10}$

Of course few if any of Valadão's Portuguese readers would have been in a position to check his facts, even if they felt inclined to do so. The Salazar regime itself was undoubtedly pleased with his report, one that not only reinforced the state's portrayal of communism as a diabolical and dehumanizing force in the world, but also cast the victims of Soviet violence as particularly innocent and vulnerable, and in need of protection. It is clear from what Valadão wrote that he heard what he wanted to hear from the refugees he met in Vienna, and was

\footnotetext{
${ }^{10}$ I am indebted to Dr. Róbert Győri for his assistance and advice on the case of the Benedictine College in Győr. Robi was himself a student at this school in the early 1990s, and notes that there was never any mention of a massacre in 1956.
} 
Jobbitt, Steven. "Hungarian Martyrs, Refugees, and the Politics of Anticommunism in Salazar's Portugal, 19561957." Hungarian Cultural Studies. e-Journal of the American Hungarian Educators Association, Volume 9 (2016) DOI: $10.5195 /$ ahea.2016.263

especially keen to pass on stories of both real and purported Soviet atrocities. For instance, according to Valadão, women and in particular girls were the primary focus of the Soviet reprisals that began on November 4, 1956. "In the neighborhoods conquered by the Soviet soldiers," he wrote, "girls and women are the first innocent victims of the savage instincts of the soldiers. Many times, after having their honor and dignity violated, they are shot without mercy by men who simply enjoy killing" [Nos bairros conquistados pela soldadesca soviética, as raparigas e senhoras são as primeiras e inocentes vítimas de instintos selváticos e, muitas vezes, depois de tocadas no mais íntimo da sua honra e da sua dignidade, são fuziladas sem dó nem piedade pelo simples gosto de matar] (21). Having already implored his audience to consider their own daughters when contemplating the events in Hungary (7), Valadão was careful to paint a picture of a defeated nation ravaged by soldiers for whom sexual violence and rape was nothing more than a game. The fate of some young girls at an unnamed school in Budapest provided a case in point. Noting that the eldest child at the school was no more than twelve, Valadão recounted the horrific scene when the first soldiers arrived and, banging on the door, announced "amidst bursts of laughter" to the two female teachers in charge of the children that "The soldiers have come to take the girls" ['Os soldados vêm buscar as meninas, 'dizem entre gargalhadas] (22). Like the story of the Benedictine College in Györ, there is no historical evidence to back up Valadão's claims. Though sexual violence was no doubt perpetrated on some level during the fighting that followed in the wake of the Revolution, the general consensus amongst scholars that I have consulted with while writing this article is that the Soviet troops were much more restrained in 1956 than they were at the end of World War II. Regardless of the questionable veracity of the stories he heard, therefore, Valadão was clearly ready to believe and perhaps even embellish them in order to paint a picture of the superior moral character of Hungary's heroes and martyrs. As Valadão makes clear, the collective sacrifice of virtuous Hungarians who fought against the barbarism of communism was not just something that should be praised, it was something that Portuguese citizens, in their combined duties as patriots and good Christians, should strive to emulate.

The violence and barbarism that Valadão wrote about ran parallel with a second purpose behind the pamphlet, which was to remind - or perhaps to persuade and convince-Portuguese citizens that they should consider themselves well off and lucky if they compared their own lives to those of their contemporaries in Hungary. Indeed, beyond serving as a vehicle for propagandizing the horrors of Soviet atrocities and the tyranny of the communist system more generally, the memory of those who had fallen, coupled with a discussion of the desperate conditions which had compelled Hungary's martyrs to rise up in the first place, provided a useful point of comparison (and maybe even a warning) for anyone in Portugal who might be inclined to question his or her own material circumstances and physical wellbeing. Again, Valadão's pamphlet is revealing. Suggesting quite clearly that the Portuguese people were fortunate to live where they did, Valadão wrote:

"It is important and useful to remind ourselves that, in the heart of Europe, in the lands that were once the symbol of happiness and the lack of worry, an entire people moans under tyrannical oppression, and that, at this moment, while we are warm and comfortable in our homes, millions of people are happy with a little bit of coal and find comfort in the news that some of their relatives have not yet been killed."(6) 
Jobbitt, Steven. "Hungarian Martyrs, Refugees, and the Politics of Anticommunism in Salazar's Portugal, 19561957." Hungarian Cultural Studies. e-Journal of the American Hungarian Educators Association, Volume 9 (2016) DOI: $10.5195 /$ ahea.2016.263

[Importa e convém lembrarmos uns aos outros que, no coração da Europa, em terras que outrora foram símbolo de alegria e despreocupação, um povo inteiro geme sob a tirânica opressão e que neste mesmo instante, em que nos aquecemos ao calor dos nossos lares e no conforto das nossas casas, milhões de pessoas consideram como alegria maior um pouco de carvão e como conforto sem igual a notícia de que alguns dos seus não foram ainda chacinados.]

The message was a simple but important one: Portuguese citizens should be grateful to live in a country that protected its citizens from the depravity of communism, and that nurtured rather than persecuted its people. In this light, Valadão went to great lengths to describe the restrictions imposed on Hungarians in the decade since the end of World War II, echoing as he did so some of the key rhetorical mainstays of Cold War anticommunist propaganda. Above all else, he reminded his readers that communists were dangerously secular and atheistic and, like the Nazis, were aggressive in their suppression of the Church and religion more generally (1011). Catholics in particular had much to fear in communist Hungary, and could only engage secretly in the practice of their faith. What remained of the Catholic Church under communism was a mere shadow of its former self. With many priests imprisoned and subjected to torture and other forms of state-sanctioned violence, the Church had been effectively "decapitated" in Hungary and, as in other communist states, was nationalized by the communists. Forced to function "independently from Rome" [independente de Roma], the Church could no longer serve either God or the people (11).

Though the attack on the Church and the suppression of faith was perhaps of paramount concern, Valadão was careful to also point out other ways in which communism corrupted Hungarian society and oppressed the people. People were no longer free to choose where they worked, for example, and were forced to labor under conditions that were unjust and even punitive. "Hunger and misery" [a fome e a miséria] constituted the cross that the Hungarian worker was forced to bear, while all Hungarians - and in particular the "pariahs of society" who belonged neither to the party nor the nomenklatura - suffered from the rationing and general austerity that defined the Stalinist state (13-14).

Censorship was also a reality of life under communism, Valadão warned, as was a complete rejection of the Western way of life and thinking. The education system itself, he noted, had been completely transformed in an attempt to foist the communist worldview upon the youth of the nation. The teaching of Western languages was prohibited, for example, while the study of Russian became obligatory. Likewise, teachers were compelled to teach an exclusively Marxist-Leninist curriculum, while university professors found themselves having "to perform prodigious acrobatics to avoid making reference in their courses to any grand figure of Western science" [os professores universitários eram obrigados a malabarismos prodigiosos para evitar a referência nos seus cursos a qualquer grande figura da ciência ocidental] (14). Underscoring the severity of the restrictions placed on individual liberty in the Soviet system, Valadão concluded:

Above all else, it has been terror that has characterized the atmosphere in Hungary during the last ten years of communist tyranny. [...] Immense terror has asphyxiated this people, who despite everything continue to work, suffer, and 
pray, but who cannot know for certain what even their parents or neighbors are thinking. It is because of this that it has become prudent for people to be suspicious of everything and everyone.

[o que acima de tudo caracterizava a atmosfera da Hungria durante os dez anos de tirania communista era o terror. [...] Terror imenso asfixiava este povo, que apesar de tudo continuava a trabalhar, a sofrer e a rezar, sem que no entanto quem quer que fosse soubesse, de certeza absoluta, o que pensava o parente ou o vizinho, pois era prudente desconfiar de tudo e de todos] (14-15).

Running parallel to this second purpose behind Valadão's pamphlet, one that exalted the Portuguese way of life under Salazar by demonizing the society created in Hungary under communism, was a third message or "lesson," namely that the people of Portugal, like the heroes and martyrs of revolutionary Hungary, must be prepared to sacrifice themselves for a higher ideal. Having outlined a world defined by ideological struggle and civilizational threats, Valadão reminded his readers in no uncertain terms that Portugal was a Catholic nation whose destiny was to reclaim and uphold the moral and cultural values of Western civilization. With a nod to the interconnected celebrations of death and martyrdom that have in part defined the worldviews of fascist and quasi-fascist movements in Europe throughout the twentieth century, Valadão suggested that the willingness of Hungarian revolutionaries to die for a noble cause and to sacrifice themselves for their nation provided a good example for Portuguese citizens, and especially the youth. It was the young people of Hungary, after all, who lit the spark that ignited the revolution, and who liberated the country — if only briefly - from "ten years of suffering and martyrdom; ten years of endless torment" [dez anos de sofrimento e martíro; dez anos de tormentos sem conta] (25). On the initiative of a handful of students who were no longer prepared to live with the indignities and oppression that defined their lives under communism, an entire nation rose up in defiance of their tormentors. For this reason it was the youth who should be celebrated above all others. As he wrote:

It was in truth the youth who revolted in Budapest against communism, and it was the young who were often amongst the first to die at the barricades, or under tanks, or on street corners or in the windows of houses...To hear descriptions of the fighting in Budapest, it is impossible not to admire the heroism of the Hungarian youth (17-18).

[Foi, na verdade, a juventude que se revoltou em Budapeste contra o communism e foi a juventude, muitas vezes das primeiras idades, que morreu nas barricadas, debaixo dos tanques, nas esquinas das ruas e até nas janelas das casas...Ao ouvir as descrições da luta em Budapeste, necessáriamente admirava o heroismo da mocidade húngara].

Brave as they may have been, the young men and women who stood against their oppressors in the streets of Budapest and other Hungarian cities were armed with more than just their courage. According to Valadão, these young heroes and martyrs were also guided by clarity of vision, one that he attributed to the moral fortitude and spiritual resistance of the Hungarian 
youth. Despite having come of age in a society dominated by communist institutions and discourse, the youth of Hungary had nevertheless been able to resist nearly a "full decade of terrible communist indoctrination" [dez anos de terrivel doutrinação] (17), and were clearly motivated by ideals preserved from an earlier time. As Valadão asserted, Hungary's revolutionary heroes were praiseworthy precisely because they had not allowed themselves to become "contaminated" by communism.

The story of a young man injured in the fighting in Budapest illustrated the moral and ideological purity that Valadão saw in Hungarian revolutionaries. Recuperating in Vienna, this wounded "refugee" [ refugiado] informed Valadão of what he had witnessed in the streets of Budapest, and wept when he spoke of a family he would never see again. When asked pointedly about his politics and what party he belonged to, Valadão's informant responded that he was not political and that he had no party. Assisted to his feet by the priest who was comforting him, he raised his hands and pointed to the crucifix on the wall, saying: "My politics is this, just this!" [a minha política é esta, só esta] (28).

If Hungary's Revolution had obvious heroes that Valadão could point to as a means of rallying the Portuguese people around a higher ideal, there were also perceived counter-examples of treachery and cowardice that could be mobilized for similar propagandistic ends. One such counter-example stands out in particular. Noting that Hungary's Catholic priests had for the most part acted heroically by maintaining a defiant anticommunist stance both before and during the Revolution, Valadão was nevertheless careful to point out that some priests instead sought a compromise with the communist state, and were complicit in helping the Rákosi regime nationalize the Church. Acting out of self-interest and cowardice, these priests stood in sharp contrast to their Catholic brethren who, motivated by moral principles rather than opportunism, faced their martyrdom "proudly and heroically" [orgulhosa e heróicamente] (11). Though he does not state it explicitly, Valadão was clear in his message that the Portuguese people, like the heroic Hungarian priests, needed to be prepared to fight and willing to die for their ideas, and for their nation. To do otherwise would be shameful, and ultimately treasonous.

It is always difficult to discern the extent to which groups of people internalize and understand propaganda. Nevertheless, judging by the nature of the telegrams and letters sent to the Salazar government by Portuguese citizens expressing their support for the Revolution and for the victims of Soviet reprisals, it is clear that the events in Hungary captured the popular imagination of the Portuguese people. A telegram transmitted on November 10, 1956 from the crew of the naval vessel Conceição Maria provides a good case in point. Though they were at the time "navigating the high seas" [navegando alto mar], the crew was following the news of the Revolution closely, and felt it necessary to ask the Minister of the Navy (Ministro da Marinha) to convey personally to Salazar their "great indignation and vehement protest against the monstrous crime" being perpetrated against the Hungarian people [nossa maior indignação $e$ veemente protesto contra o monstruoso crime perpetrado]. Drawing upon the language of martyrdom and sacrifice that in large part defined the official discourse surrounding the 
Jobbitt, Steven. "Hungarian Martyrs, Refugees, and the Politics of Anticommunism in Salazar's Portugal, 19561957." Hungarian Cultural Studies. e-Journal of the American Hungarian Educators Association, Volume 9 (2016) DOI: $10.5195 /$ ahea.2016.263

Revolution and its suppression, the crew declared themselves to be in mourning over the events in Hungary and the suffering of its people. ${ }^{11}$

Whether or not the telegram represented a genuine response of the ship's crew or was simply a calculated political-ideological performance based on government propaganda is a good question to ask, if perhaps difficult to answer. By way of beginning to answer this question, it is important to note that the events of the Revolution in Hungary did move Portuguese people to action, and this in at least two different and important ways. One was to take part in public demonstrations in support of Hungary's heroes and martyrs. A telegram sent by Augusto Cesar de Carvalho, an official with the civil government of the district of Guarda [governo civil da Guarda], is a good example of the "spontaneous" public protests that appear to have taken place in Portugal at the end of October and beginning of November 1956. Dated November 7, and addressed to Salazar, Cesar de Carvalho wrote that it was his "honor" to transmit the message of the city's students and "some thousands of its residents" [alguns milhares habitantes] who had gathered in a public demonstration against "the crimes committed by Russian imperialism against the heroic people of Hungary" [os crimes cometidos pelo imperialismo Russo na heroica população Hungara]. Accompanied by the "illustrious prelate of the diocese" [ilustre prelado da diocese], the people of Guarda, led by its youth, gathered to express their "unanimous rejection of Moscow's barbarism, and of the ideology that inspires and informs it" [sua repulsa pela barbarie Moscovita e pela ideologia que a inspira e a informa]. The heroism and collective suffering of Hungary's "martyrs" [martires] was not surprisingly central to the telegram. Cesar de Carvalho assured Salazar that the people of Guarda stood in solidarity with the Hungarian heroes who "fell in defense of the ideas and principles that inform all of Western civilization" [os heroicos martires Hungaros que tombaram em defesa do ideais e principios que informam toda a civilização do Ocidente]. Demanding that Portugal continue to stand with the international community in its condemnation of Soviet aggression and in its calls for "the complete liberation and independence of the Hungarian nation" [ a completa libertação e independencia da nação Hungara], the demonstrators encouraged the Portuguese government to do all it could to act on its promise to aid "the martyred people of Hungary" [as populações martirizadas da Hungria]. ${ }^{12}$

A second way that Portuguese people were moved to action by the events in Hungary was to volunteer to house Hungarian refugees seeking asylum in Portugal. A handwritten letter from João de Abreu from the northern city of Guimarães is a good illustration of this voluntarism, and more importantly demonstrates the way in which individual citizens employed official state discourse alongside pre-exiting Western European stereotypes of Eastern Europe in

\footnotetext{
${ }^{11}$ ANTT, AOS/CO/PC-46, Pt. 13, “Correspondência sobre as seguintes questões: Manifestações e protestos contra a agressão soviética à Hungria" ['Correspondence Concerning the Following Questions: Demonstrations and Protests against Soviet Aggression in Hungary'], telegram sent from the crew of the Conceição Maria to the Minister of the Navy, November 10, 1956.

${ }^{12}$ ANTT, AOS/CO/PC-46, Pt. 13, “Correspondência sobre as seguintes questões: Manifestações e protestos contra a agressão soviética à Hungria" ['Correspondence Concerning the Following Questions: Demonstrations and Protests against Soviet Aggression in Hungary'], telegram from Augusto Cesar de Carvalho, Governo Civil da Guarda ['Governor of the District of Guarda'] to Salazar, November 7, 1956.
} 
Jobbitt, Steven. "Hungarian Martyrs, Refugees, and the Politics of Anticommunism in Salazar's Portugal, 19561957." Hungarian Cultural Studies. e-Journal of the American Hungarian Educators Association, Volume 9 (2016) DOI: $10.5195 /$ ahea.2016.263

order to make their appeal to the Portuguese government. Dated November 10, 1956, and addressed to Salazar, de Abreu began his letter by praising the actions of the Portuguese state, stating that, "in its support of the revolt of heroic and resistant Hungary against Soviet banditry," the Portuguese people were acting "in accordance with the traditions of the glorious Lusitanian race, which has been and continues to be a nation of warriors, heroes, and saints" [seguindo a tradição desta gloriosa Raça Lusitana, que foi e é Patria de guerreiros, herois, e santos, eis que Portugal está presente nos actos de revolta contra o banditismo soviético sobre a heroica e resistente Hungria]. It was out of altruism, he continued, that Portugal stood on the side of justice and morality both in their support of "this martyred people" [esse martirisado povo] and in their condemnation of the actions of "cruel and savage Soviet assassins" [ aos crueis $e$ selvagens assassinos soviéticos]. ${ }^{13}$

Painting a picture of communist Hungary and Eastern Europe more generally as "faraway lands" [longínquas terras] where "death is vomited forth from the mouths of cannons with great indifference" [onde a boca dos canhões vomita a morte com a maior das naturalidades], de Abreu lamented the fate of innocent victims caught behind the Iron Curtain, a world in which "men kill each other minute by minute primarily because they have forgotten that they must obey and respect the Christian Doctrine that Christ proclaimed for the Universe" [os homens aniquilam-se minuto a minuto porque esquecem que acima de tudo, deve ser cumprida e respeitada a Doutrina Cristã que Cristo pregou no Universo]. Inundated by "blood that flows in torrential rivers" [ao sangue que fazem deslizar como caudalosos rios], the communists were particularly indifferent to the orphans they had created. By thus caring for the innocent who had been displaced by Soviet tyranny and Eastern barbarism, Portugal would set a good example for the Christian West, and would continue to enhance "the prestige of our country" [o prestigio da nossa Pátria] in the eyes of others. It was in this light that de Abreu asked for permission "to house and educate a couple of Hungarian children" [recolher e educar um casal de criancas hungaras], thus saving them from "the demonic fire of a people without faith, religion, or pious sentiments" [o fogo demoniaco dum povo sem Fé, sem Religião, sem sentimentos de piedade]. ${ }^{14}$

There is no indication in the archival record whether or not de Abreu's petition resulted in refugee children being sent to him. It is, however, likely that his request was given serious consideration. According to a UN report dated November 19, 1956, as well as a NATO report published in April 1957, Portugal was willing to offer temporary asylum to as many as seven thousand unaccompanied minors, along with some children and their mothers (UN General Assembly 1956: Annex p. 3, NATO 1957: 12; see also Zieck 2013: 56-57). When compared to the numbers of Hungarians accepted by other countries, the potential intake by the Salazar regime of so many young Hungarians is on some level impressive, though it is doubtful that

\footnotetext{
${ }^{13}$ ANTT, AOS/CO/PC-46, Pt. 13, “Correspondência sobre as seguintes questões: Manifestações e protestos contra a agressão soviética à Hungria" ['Correspondence Concerning the Following Questions: Demonstrations and Protests against Soviet Aggression in Hungary’], letter from João de Abreu to Salazar, November 10, 1956.

${ }^{14}$ ANTT, AOS/CO/PC-46, Pt. 13, “Correspondência sobre as seguintes questões: Manifestações e protestos contra a agressão soviética à Hungria" ['Correspondence Concerning the Following Questions: Demonstrations and Protests against Soviet Aggression in Hungary’], letter from João de Abreu to Salazar, November 10, 1956.
} 
Jobbitt, Steven. "Hungarian Martyrs, Refugees, and the Politics of Anticommunism in Salazar's Portugal, 19561957." Hungarian Cultural Studies. e-Journal of the American Hungarian Educators Association, Volume 9 (2016) DOI: $10.5195 /$ ahea.2016.263

more than a few hundred ever came to Portugal, and almost none appear to have stayed for more than a year. ${ }^{15}$ In fact, according to UN sources, a total of only four Hungarian refugees were resettled in Portugal on a permanent basis by Spring 1958, one less than the number taken by Cuba, and exactly the same number as were resettled in Nicaragua (Holborn et al. 1975: 414-15, Colville 2006: 10, Zieck 2013: 59). The failure - or perhaps inability - to accept more Hungarians on a long-term basis is curious, at least given the rhetoric of the Salazar regime in late October and early November 1956. Despite celebrating the Hungarian people as heroes and martyrs, the intake of unaccompanied minors and children fell far shy of its promised "target," while adult refugees were not welcomed into Portugal in large or even significant numbers, not even as temporary asylum seekers. In part the reason lies in the fact that many Hungarians sought refuge and new opportunities in other countries, and especially in the Americas (in particular the US and Canada). As the above-mentioned NATO report indicated, Hungarians fleeing Hungary wished "to the put the ocean behind them" (7). But Portuguese archival sources indicate that adult refugees (both individually and in large groups) did seek asylum and longterm opportunities in Portugal. The question then remains: Why did the Portuguese state reject these petitions for asylum and resettlement?

In part the Portuguese rejection of adult refugees was grounded in practical considerations: Portugal simply lacked the material resources and infrastructure to accommodate large numbers of migrants (at least this was the general explanation given by Portuguese officials in the documents examined for this study). Perhaps more importantly, however, the revolution itself and the displaced people it produced were politically problematic for the Salazar regime. Beyond running the risk of granting asylum to actual communists, Portuguese officials must have been aware of the irony inherent in their support of Hungary's "freedom fighters." On the surface, the Estado Novo was a new model for a brave new world, one that promised to negotiate the "modern" on its own terms, and to offer security, stability, and prosperity to its citizens. In reality, Salazar's Portugal was built upon deliberate underdevelopment at home and a repressive imperial system abroad (particularly in Africa). Given the postwar efforts of leading Western nations to reform their domestic policies and to at least pay lip service to decolonization, the Salazar state was very much a political and ideological, not to mention cultural, outlier. Though the Portuguese response to the Hungarian crisis shared much in common with other countries in Europe and the Americas, the practical limitations of the Estado Novo, coupled with the political tensions embedded in Salazar's authoritarian state-building project, created unique conditions

\footnotetext{
${ }^{15}$ My own father-in-law, who turned thirteen in November 1956, remembers that his grandparents in Setubal, Portugal housed two Hungarian teenage girls in late 1956 and early 1957, but that they only stayed for a few months, after which the family lost touch with them. In his pioneering work on "under-age" Hungarian refugees, Béla Nóvé offers some valuable insight on the fate of young Hungarian refugees after the Revolution, and in particular the estimated 20,000 (or more) unaccompanied minors who fled Hungary in October and November 1956 (see Nóvé 2013). Of the Portuguese case, he writes about a transport of thirty "orphans of the revolution" who were housed temporarily in a children's home near Lisbon (likely in Santa Mare de Oeiras). According to Nóvé, one of the boys, a thirteen-year-old named Lajos Kiss who had run away from the state orphanage in Dorog (a mining town in Transdanubia) when the Revolution broke out, was even unofficially (or rather symbolically) "adopted" by Miklós Horthy, though after the former Regent's death in February 1957, "the teenage boy was dismissed, and thus exposed to all the troubles of a lone and alien child" (77). Kiss eventually ended up in the US, where he settled.
} 
Jobbitt, Steven. "Hungarian Martyrs, Refugees, and the Politics of Anticommunism in Salazar's Portugal, 1956-

1957." Hungarian Cultural Studies. e-Journal of the American Hungarian Educators Association, Volume 9 (2016) DOI: $10.5195 /$ ahea.2016.263

that handcuffed the Portuguese response to the Hungarian Revolution and the refugee crisis that it produced.

\section{Refugees and the Internal Contradictions of Salazar's Estado Novo}

An examination of a selection of letters and official petitions sent to the Salazar government by Hungarians and by different Portuguese individuals and interest groups highlights the deficiencies of Salazar's Estado Novo, and helps to explain the very modest intake of Hungarian refugees to Portugal. There was, in fact, no shortage of Hungarians seeking either refuge or a new life altogether in Portugal in the months following the revolution, with the existing archival record providing a broad - if incomplete - picture of the kinds of petitions received by the Portuguese government in 1956 and 1957.

One file from the Portuguese Legation in Stockholm is especially revealing in this light. Though unfortunately thin, the file nevertheless contains the letters of two Hungarian asylum seekers who, having found temporary refuge in Sweden, were seeking long-term opportunities in Portugal. The first letter (written first in German and then translated into French) was sent by Istvan Lövinez, a refugee who had made his way to Sweden via Austria. Identifying himself as a Hungarian boxer who had once been named to the Hungarian national team, Lövinez began his letter by indicating that he was unable to practice his sport in Sweden because he could not find work. Having written to inquire about what might be required in order to immigrate to Portugal, Lövinez presented himself as a humble worker who simply wanted to box. "I build houses," he wrote, "and I would like to find similar work in this field so that I can earn a little; I would like just as much to be able to continue with my sport" [Je construis des maisons et je voudrais travailler quelque part en cette branche pour gagner un peu; et je desire également continuer avec mon sport]. Having no doubt sent this same letter to the embassies and legations of other countries, he concluded with a question: "What are the conditions for immigration in your country?" [Quelles sont les conditions d'immigration en votre pays?]. ${ }^{16}$

The second letter in this same file was from Dr. Gyula Nemes, a gynecologist who received his diploma from the University of Budapest in 1954, and who was working at the Central Hospital of the Hungarian State Railway at the time of the Revolution. Like Lövinez, Nemes had found temporary asylum in Sweden, and was looking for long-term employment opportunities. Writing in English, Nemes indicated that he was "very interested in Portugal" and that he was "curious to know more about the possibilities which are given to immigrate to Portugal, or to some of your colonies." Noting that he had served as "the president of the National Revolution Committee in [his] hospital," Nemes wrote that he had been forced to flee Hungary after the failure of the Revolution, and that he "should like to get some medical job" in Portugal. $^{17}$

\footnotetext{
${ }^{16}$ ANTT, AOS/CO/NE-25, Pt. 2, “Correspondência sobre as seguintes questões: Pedido de concessão de asilo politico em Portugal para refugiados húngaros" ['Correspondence Concerning the Following Questions: Petitions for the Granting of Political Asylum in Portugal by Hungarian Refugees'], letter from Istvan Lövinez to the Portuguese Legation in Stockholm, Sweden. N.d. (received by the Legation office on January 12, 1957).

${ }^{17}$ ANTT, AOS/CO/NE-25, Pt. 2, “Correspondência sobre as seguintes questões: Pedido de concessão de asilo politico em Portugal para refugiados húngaros" ['Correspondence Concerning the Following Questions: Petitions
} 
Jobbitt, Steven. "Hungarian Martyrs, Refugees, and the Politics of Anticommunism in Salazar's Portugal, 19561957." Hungarian Cultural Studies. e-Journal of the American Hungarian Educators Association, Volume 9 (2016) DOI: $10.5195 /$ ahea.2016.263

Once again, there is no indication in the archival record of what action Portuguese officials took in either of these cases, though given the few refugees who were resettled by the Salazar regime it is almost certain that neither Lövinez nor Nemes ended up in Portugal. In fact, none of the petitions for long-term asylum in Portugal that remain in the national archives appear to have been approved. As noted above, one of the principal reasons for rejecting Hungarian applications to immigrate to Portugal was a perceived lack of resources and infrastructural support. Of all the petitions examined for this study, the case of the faculty from the University of Sopron's School of Forestry stands out, and points very clearly to Portugal's limited capacity to receive refugees, at least when dealing with professionals like Nemes or academics like those from Sopron. Though the entire faculty would ultimately end up at the University of British Columbia in Vancouver (Hidas 1998), it is clear from the letters and petitions preserved in the archives that the professors and students from Sopron were anxious that they would manage to find a host country that would be prepared to accept 30 teachers and their families as well as 250 students, and that would be capable of providing space in one of its universities so that they could continue their work.

On November 24, 1956 the Board of Professors of the University of Sopron (then located in Vienna) sent a petition directly to Salazar, outlining the desire of the faculty of the School of Forestry to be relocated as an entire group along with their students and families. Noting that they had the support of the International Rescue Committee in Austria, they indicated that they had already approached many countries and that they were now reaching out to Portugal in the hopes that the Portuguese state might be willing to help them. Stating that an estimated 1.5 million US dollars would be required over the first 5 years, they nevertheless promised that the investment would be a worthwhile one, if not for financial reasons, then at least for culturaland even moral and civilizational-reasons. Writing in halting English, they argued: "We can not give anything for the help but thanks of our people, thanks of mothers and fathers, which will give you recognition of history. This recognition means more than any material equivalent and will prove that the value of life does not increase by material goods but by the unexhaustive depth of the human soul." 18

Judging from the surviving correspondence, Portuguese officials gave careful consideration to the petition they received from the faculty of the School of Forestry. The Minister of Education, in fact, submitted a four-page handwritten reply directly to Salazar on December 20, 1956. Indicating that he had read the appeal "with great interest" [com o maior interesse], the minister provided a brief contextual overview of the University of Sopron, situating it within the history of higher education in Hungary itself. The university, he wrote, had

for the Granting of Political Asylum in Portugal by Hungarian Refugees'], letter from Gyula Nemes to the Portuguese Legation in Stockholm, Sweden. January 7, 1957.

18 ANTT, AOS/CO/PC-46, Pt. 13, “Correspondência sobre as seguintes questões:Manifestações e protestos contra a agressão soviética à Hungria" ['Correspondence Concerning the Following Questions: Demonstrations and Protests against Soviet Aggression in Hungary'], letter from the Board of Professors of the University of Sopron to Salazar, November 24, 1956. See also the Portuguese translation of the letter in the same file sent to Salazar from the Sectretariado Nacional da Informação, Cultura Popular e Turismo, Secção de Imprensa Estrangeira ['National Secretary of Information, Popular Culture, and Tourism, Foreign Press Section']. December 12, 1956. 
Jobbitt, Steven. "Hungarian Martyrs, Refugees, and the Politics of Anticommunism in Salazar's Portugal, 19561957." Hungarian Cultural Studies. e-Journal of the American Hungarian Educators Association, Volume 9 (2016) DOI: $10.5195 /$ ahea.2016.263

grown out of a much smaller institution founded in the nineteenth century, and at the time of the Revolution included faculties of Humanities, Biological Science, Physical Science, Mathematics, and Engineering (a faculty that specialized in mining and "geographical engineering" [engenheiros geografos]). Because of their proximity to Austria, many faculty members and students of the university were able to flee to Vienna, where they were now seeking relocation to other host countries. As to whether or not Portugal would be capable of accommodating the School of Forestry, the minister was clear that this was, in his opinion, not feasible. In the first place, none of Portugal's existing universities had the space or the resources to house the school in its entirety, nor could the ministry itself afford to pay for the upgrades to existing laboratories that would be necessary for research-intensive silvicultural studies. In addition, Portuguese professors and students lacked the necessary language skills to facilitate the full integration of the School of Forestry into the existing Portuguese system. English, he wrote, could possibly serve as a means of communication between Hungarian and Portuguese professors, "but it could never serve as the language of instruction" in a Portuguese university [mas nunca poderia servir como idioma de ensino $]^{19}$

Similar to the case of the Sopron School of Forestry, the Portuguese government also rejected a proposal put forward by the Portuguese Legation in Vienna to accept "a few hundred farm laborers" [algumas centenas de lavradores] for resettlement in the Portuguese colonies of Angola and Mozambique. Though government officials admitted that it "would be easy" [seria fácil] to authorize the resettlement of refugees and to grant land concessions to Hungarian immigrants, the Minister of the Colonies [Ministro do Ultramar] responsible for Portugal's overseas possessions wrote in a memo that "the aid necessary to support those in need would be very costly" [o restante auxílio que seria necessário para quem nada possui, torna-se muito oneroso]. It would simply be too difficult, he continued, to support Hungarian refugees in Portugal's two main African possessions. Of course, the situation might change completely "if some international organization was willing to finance the establishment of most of the families" in Angola or Mozambique [o caso mudaria de figura se qualquer organismo internacional estivesse disposto a finaciar o estabelecimento de bastantes famílias]. However, given Portugal's situation at the time, the minister felt it would only be possible to accommodate at most about ten families [uma dezena de famílias] in a few cities (namely Cela and Matala in Angola and Limpopo in Mozambique). Though a far cry from the few hundred originally proposed by the Legation in Vienna, the resettlement of a handful of Hungarian refugees would at the very least have "symbolic value" [valor simbólico ${ }^{20}$

${ }^{19}$ ANTT, AOS/CO/PC-46, Pt. 13, "Correspondência sobre as seguintes questões:Manifestações e protestos contra a agressão soviética à Hungria" ["Correspondence Concerning the Following Questions: Demonstrations and Protests against Soviet Aggression in Hungary'], letter from the Minister of Education to Salazar, December 20, 1956.

${ }^{20}$ ANTT, AOS/CO/PC-46, Pt. 13, “Correspondência sobre as seguintes questões:Manifestações e protestos contra a agressão soviética à Hungria" ['Correspondence Concerning the Following Questions: Demonstrations and Protests against Soviet Aggression in Hungary'], Memorandum from the Office of the Minister of the Colonies [Ministro do Ultramar]. November 13, 1956. There is no indication in the archival record that any refugees were 
Jobbitt, Steven. "Hungarian Martyrs, Refugees, and the Politics of Anticommunism in Salazar's Portugal, 19561957." Hungarian Cultural Studies. e-Journal of the American Hungarian Educators Association, Volume 9 (2016) DOI: $10.5195 /$ ahea.2016.263

Although various practical considerations were perhaps the primary reason for rejecting large numbers of Hungarian refugees, it is clear from the sources that political and ideological concerns were not far from the surface as Portuguese officials scrambled to respond effectively to the European-wide crisis the Revolution had spawned. ${ }^{21}$ Though the sources consulted for this article reveal very little about how the Salazar regime viewed Hungarians as potential immigrants to their country, there can be no doubt that officials were concerned about the potential threat posed by at least some of the people fleeing Hungary in the wake of the revolution, especially those who played an active political or ideological role in the uprising itself. A memo concerning the possibility of accepting Sopron's School of Forestry faculty sent to Salazar from the headquarters of the Legião Portuguesa ['The Portuguese Legion,' a paramilitary pillar of Salazar's Estado Novo] indicates that asylum seekers were likely being screened carefully within the context of the government's discussion of the refugee question. ${ }^{22}$ Though the Legião saw no potential threat in the faculty from the School of Forestry, it is clear that Portuguese officials were concerned about the nature of the refugees that might end up in their country. Like many other Western nations, the Portuguese undoubtedly feared that communist agents and sympathizers would make use of the refugee crisis in order to infiltrate non-communist countries (see, for example, Donaghy 2010: 256). "Legitimate" refugees may have deserved Portuguese sympathy and support, but the risk to the nation posed by potential spies and political agitators was real, at least in the eyes of the government.

Beyond the need to control the flow of refugees into the country, the Salazar regime was also clearly anxious to manage and monitor the discourse, symbolism, and hence political and ideological meaning of the Hungarian Revolution itself. Given the domestic situation both politically and economically, there was a real danger that Portuguese citizens would ignore the anti-Soviet, anticommunist message offered by the official propaganda surrounding the Revolution, and would instead be inspired by representations of the popular revolt as a heroic and ultimately democratic uprising of the people against the social, political, and economic injustices of an authoritarian state system. Valadão's pamphlet once again provides some insight for our consideration, and points to evidence that suggests that there were people in Salazar's Portugal who spoke out against the official state interpretation of both the Revolution and the purported motivations of the Hungarian people. Valadão was particularly indignant in his condemnation of a well-known (though unnamed) Portuguese intellectual who dared to make comparisons between the state system in communist Hungary and the state system in "certain countries in the West" [doutro país do Ocidente]. Though Valadão does not name Portugal explicitly in this condemnation, it is clear that he was responding to a critic who saw through the

resettled in Portugal's two largest African colonies. It is highly unlikely, if fact, that any ever were.

\footnotetext{
${ }^{21}$ Although more work needs to be done on this question, it is quite likely that Portuguese authorities were also concerned that amongst the refugees seeing asylum at least some would have been Jewish.

${ }^{22}$ ANTT, AOS/CO/PC-46, Pt. 13, “Correspondência sobre as seguintes questões:Manifestações e protestos contra a agressão soviética à Hungria" ['Correspondence Concerning the Following Questions: Demonstrations and Protests against Soviet Aggression in Hungary'], Memorandum from the Headquarters of the Legião Portuguesa to Salazar. December 17, 1956.
} 
Jobbitt, Steven. "Hungarian Martyrs, Refugees, and the Politics of Anticommunism in Salazar's Portugal, 19561957." Hungarian Cultural Studies. e-Journal of the American Hungarian Educators Association, Volume 9 (2016) DOI: $10.5195 /$ ahea.2016.263

hypocrisy and insincerity of Portuguese propaganda, and who had the audacity to suggest parallels between Salazar's Estado Novo and the Stalinist system that had defined Hungary and the rest of the East Central Europe since the end of World War II (15).

There is no doubt that some scholars would question the parallels that Valadão's unnamed critic drew between the tyranny of the Stalinist state and the authoritarian basis of Salazar's Estado Novo. However, despite the obvious ideological differences, the points of comparison between Salazar's Portugal and Rákosi’s Hungary are considerable, and are important to take into consideration. It is worth pointing out, for example, as Tony Judt does in his monumental study Postwar, that the standard of living in Portugal under Salazar "was comparable to that of Eastern Europe" under communism (504), and that from a political point of view the Estado Novo worked tirelessly to smother dissent and crush any vestiges of meaningful democratic opposition (511). As Judt concludes, "Salazar's authoritarian reign [was] peculiarly and self-consciously retrograde even by the standards prevailing when he first took over power in 1932" (510). Though the period from 1949 to 1957 saw a temporary realignment and even "retreat" of hardline revolutionary resistance to the Salazar regime (Raby 1988: 107-129; Gómez 65-68), the material conditions domestically coupled with growing political discontent and radicalism at home and abroad contributed to what Raby has identified as "the emergence of vigorous new tendencies within the [Portuguese] resistance" (which included not only a reformed communist movement but also the rise of left-wing "populism" within the military and the emergence of the Catholic Left) (7). Much like the Rákosi regime in Hungary, which according to János Rainer (2010) "entered into an actual state of war against society" in the face of economic crises and general tensions caused by "the pursuit of irrational economic plans" and political oppression (14), Salazar and his supporters found themselves preparing for a massive fight with their own people, one that would break out in earnest in 1958, and which would quickly accelerate after the outbreak of the colonial revolt in Angola in January 1961 (Raby 1988).

When we think, therefore, about how people in Portugal might have perceived events in Hungary, it is possible that, at the very least, leftist intellectuals and political dissidents might have been able to make a case that communist Hungary was by some measures more progressive than Salazar's Portugal, at least when one takes into consideration the revolutionary, antiaristocratic nature of the reforms implemented by the communist state in Hungary after their consolidation of power in 1948-1949. Whereas the majority of Portugal's citizens languished in "poverty and near-medieval isolation" (Raby 1988: 2) under "hierarchies of authority" borrowed from another era and frozen into place by the Salazar regime (Judt 2005: 504, see also Mailer 1977: 65-67), at least some Hungarian workers and peasants had benefitted (albeit unevenly and not without violence and considerable hardship) from sets of reforms aimed at overturning an imbalance of social, political, and economic power that had emerged in Hungary over the course of the nineteenth century, and which had been rearticulated both ideologically and structurally by Horthy's conservative-nationalist regime in the interwar period. As Rainer reminds us, 1956 embodied a continuation of, rather than a break from, the "reformist thinking" that had existed in Hungary and in progressive movements throughout Europe since at least World War I. Far from being led by reactionary impulses aimed at returning Hungary to its interwar conservativenationalist foundations, Hungary's revolutionaries sought to free themselves from the tyranny of Stalinism as a means of steering the country towards a more progressive, even revolutionary, future. For Portuguese observers on the left, the Hungarian people had on some level already 
Jobbitt, Steven. "Hungarian Martyrs, Refugees, and the Politics of Anticommunism in Salazar's Portugal, 19561957." Hungarian Cultural Studies. e-Journal of the American Hungarian Educators Association, Volume 9 (2016) DOI: $10.5195 /$ ahea.2016.263

achieved and were continuing to fight for the sorts of political reforms and structural changes that Portuguese dissidents could only dream of.

Of course, it is unlikely that the leaders of the Salazar regime had a full picture of the Hungarian Revolution itself or of the people who supported and fought in it (at least not in the autumn of 1956 and the months that followed). However, it is reasonable to assume that Portuguese officials understood that the narrative was more complex than they were willing to communicate to their own people, and that the Revolution - no matter how much they told themselves otherwise - was not necessarily a rebellion against communism, but rather a popular uprising fueled as much by a progressive desire for justice as it was by a hatred of Soviet oppression and the tyranny of the Stalinist state built by Rákosi. Moreover, it is inconceivable to think that the Salazar regime was not aware of the anti-imperial dimensions of the Hungarian Revolution, and that their own celebration of Hungary's freedom fighters and martyrs might inspire groups in Portugal and its colonies (including the PCP and various anti-colonial movements overseas) who had been calling for the dismantling of the Portuguese empire in Africa, India, and Southeast Asia. As recently as 1953, in fact, colonial authorities in the Portuguese island colony of São Tomé and Príncipe had used deadly force in the town of Batepá to suppress growing anti-colonial dissent amongst its African subjects (Neto 2006). The victims of the Batepá massacre, who were and continue to be recognized as martyrs in the struggle against Portuguese colonialism, pointed to the hypocrisy inherent in Portugal's denunciation of Soviet imperialism, and only served to underscore the difficulties they faced in negotiating the discourse surrounding the heroes and martyrs of the Hungarian Revolution.

Though further research in the Portuguese archives needs to be conducted in order to determine the nature and full extent of the discussions Portuguese officials had concerning the progressive, anti-imperialist dimensions of the Hungarian Revolution as it unfolded in October and November of 1956, the very fact that Hungarian students and workers were engaged in armed rebellion against the state was an obvious source of anxiety. After all, both the sindicatos nacionais created by Salazar's Estado Novo in 1933 as well as the students' associations sanctioned by the state had been key targets of PCP infiltration since the 1940s (Raby 1987: 9). Moreover, though the PCP itself had adopted a more moderate and "peaceful" approach to their anti-Salazar resistance in October 1956, the party never abandoned its ultimate goal of overthrowing Salazar and dismantling the Estado Novo, and in April 1956 had even signed a Joint Declaration with the communist party in Spain. Condemning fascism as a "government of civil war" that divided the nation against itself, the Joint Declaration denounced the political cooperation between Salazar's Portugal and Franco's Spain, and further repudiated the "American domination of the [Iberian] peninsula." Calling for the creation of a broad-based coalition of the people not unlike that which united the diverse interest groups that fought together in the Hungarian Revolution, the declaration stressed that it was necessary for "the broadest possible political and social forces, of left and right, [to] come to an agreement" (Raby 1988: 120).

Any public demonstration not controlled directly by the Portuguese state, therefore, and especially one initiated by workers or students, was suspect for the regime. An incident surrounding an article published in the daily newspaper Diário de Manhã underscores the anxiety that government officials had with respect to spontaneous expressions of popular support for the Revolution and the Hungarian people more generally, and provides a good illustration of the state's attempts to carefully stage and control public demonstrations. In an article published 
Jobbitt, Steven. "Hungarian Martyrs, Refugees, and the Politics of Anticommunism in Salazar's Portugal, 19561957." Hungarian Cultural Studies. e-Journal of the American Hungarian Educators Association, Volume 9 (2016) DOI: $10.5195 /$ ahea.2016.263

on November 27, 1956, the Diário de Manhã reported on a meeting of the individual leaders of Lisbon's national syndicates and the presidents of Portugal's other federations of national syndicates [Federações dos Sindicatos Nacionais] that had taken place the night before, and indicated that a mass rally in support of Hungary's freedom fighters, one that would bring together all the workers of the District of Lisbon and their representatives would be held in the Terreiro de Paço (Lisbon's main public square) on December 7 at 6:00pm. Indicating that the demonstration had the unanimous support of everyone at the meeting (including representatives from the Peoples' Associations [Casas do Povo] and the Fishermen's Associations [Casas dos Pescadores]), the article stated that "it is already easy to anticipate the thousands of people" [é fácil antever já os milhares de pessoas] who will gather in the square to denounce "the despicable and vile attack on the freedom of the heroic Hungarian people" [o miserável e vil atentado à liberdade do heróico povo húngaro]. According to the article, these Portuguese workers would be taking part in what had in effect become a "workers' protest movement" [ $o$ movimento de protesto dos trabalhadores portugueses] that spoke out "in unison against the barbarism of the communists" [em unissono contra a barbárie dos communistas]. ${ }^{23}$

The fact that the reported demonstration was identified as a protest against communist villainy was of little consolation to Portuguese officials. In a letter dated the same day, the Minister of Corporations and Social Welfare [Ministro das Corporações e Previdéncia Social] wrote directly to Salazar, noting that he had read the morning's article in the Diário de Manhã, and that he had already followed up with the Head of Social Action Services [o Chefe dos Serviços de Acção Social] to clarify what had been published concerning the public demonstration by Lisbon's workers being planned for December 7. The Minister of Corporations and Social Welfare also assured Salazar that the Head of Social Action Services along with the leaders of the national syndicates had been warned to exercise "greater caution" [uma mais cautelosa vigilancia] in the future with respect to the way that news was reported in the press. ${ }^{24}$ In an internal memo also sent on November 27, the Head of Social Action Services reassured the minister that the author of the article had been in error, and that of the four major dailies, only the Diário de Manhã had published the wrong information concerning the meeting on November 26 and the decisions that had been made at it. Indeed, no public rally was being planned. Instead, a document expressing the "spiritual solidarity of the Portuguese workers with sacrifices the people of Hungary” [um manifesto de solidariedade espiritual com o sacrifício do Povo Húngaro] was being drafted, and that this document would be presented by a delegation of workers' representatives directly to the minister at 4:00pm on December 7. Having investigated

\footnotetext{
${ }^{23}$ N.a. 1956. "Os trabalhadores Portuguese concentrar-se-ão no Terreiro do Paço em 7 de Dezembro para uma pública manifestação contra o vil atentado à liberdade do povo húngaro" ['Portuguese Workers to Gather in the Terreiro do Paço on December 7 for a Public Demonstration Against the Vile Attacks on the Liberty of the Hungarian People'], Diário de Manhã. November 27.

${ }^{24}$ ANTT, AOS/CO/PC-46, Pt. 13, “Correspondência sobre as seguintes questões: Manifestações e protestos contra a agressão soviética à Hungria" ['Correspondence Concerning the Following Questions: Demonstrations and Protests against Soviet Aggression in Hungary’], letter from the Minister of Corporações e Previdéncia Social to Salazar, November 27, 1956.
} 
Jobbitt, Steven. "Hungarian Martyrs, Refugees, and the Politics of Anticommunism in Salazar's Portugal, 19561957." Hungarian Cultural Studies. e-Journal of the American Hungarian Educators Association, Volume 9 (2016) DOI: $10.5195 /$ ahea.2016.263

the erroneous mention of the purported public demonstration of workers published in the Diário de Manhã, the Head of Social Action Services discovered that the newspaper had not sent a reporter to the November 26 meeting, and that the story itself had been based upon second-hand information. ${ }^{25}$ More vigilance would no doubt be expected from the editors of the newspaper in the future.

\section{Conclusion}

In late January 1958, Professor Paul L. Tomori, president of the Executive Committee of the World Federation of Free Hungarian Youth [Comité Executiv de la Féderation Mondiale de la Libre Jeunesse Hongroise/Szabad Magyar Ifjuság Szövetsége] wrote an official letter to Salazar thanking both him and the Portuguese people for the aid and support they had given to Hungarian refugees in the time that had passed since the Revolution and its suppression in the autumn of 1956. Noting that "we love freedom, and it is for this reason that we fought our oppressors on the streets of Budapest" [nous aimons la liberté, pour laquelle nous avons combattu sur les rues de Budapest contre les opresseurs], Tomori cited a recently published report by a special committee of the United Nations, and echoed the "eloquent arguments" [argument éloquant] made on Hungary's behalf. "The people of Hungary," he declared, "had reason to defend themselves against the armed forces of a foreign power" [Le peuple hongrois avait raison de se defender contre les forces armées d'une puissance étrangère]. "We are fully confident" he added, "that the verdict of history will vindicate us" [Nous sommes en tout confiance, que le verdict de l'histoire nous donnera la raison $]^{26}$

Though Tomori's words of thanks were no doubt genuine (at least on some level), one has to wonder whether there might not have been a subtext to his letter. The gap between Portugal's pro-Hungarian discourse and its subsequent - and in the long term severely limitedactions to actually help Hungarian refugees would have been obvious to Tomori, as it was to other observers at the time. Though grateful for the help that Hungarians did receive from the Portuguese government and the Portuguese people (in addition to offering to take up to seven thousand unaccompanied minors and children on a temporary basis, the Salazar regime flew thirteen and a half tons of food to Vienna at the height of the refugee crisis, with private donors also contributing \$10,000 USD to the Austrian Red Cross; see NATO 1957: 12), it is almost certain that Tomori felt that Salazar's government could have done more, especially given that, in the final count, only four Hungarians were resettled in Portugal.

Of course, Portugal was not alone in acting slowly and in responding as they did. Like many Western countries at the time, the perception (real or imagined) of limited resources coupled with the fear of accepting politically questionable refugees from an Eastern European

\footnotetext{
${ }^{25}$ ANTT, AOS/CO/PC-46, Pt. 13, “Correspondência sobre as seguintes questões: Manifestações e protestos contra a agressão soviética à Hungria" ['Correspondence Concerning the Following Questions: Demonstrations and Protests against Soviet Aggression in Hungary'], memo from the Head of Social Action Services [o chefe dos serviços de acção social] to the Minister of Corporações e Previdéncia Social to Salazar, November 27, 1956.

${ }^{26}$ ANTT, AOS/CO/PC-46, Pt. 13, “Correspondência sobre as seguintes questões: Manifestações e protestos contra a agressão soviética à Hungria" ['Correspondence Concerning the Following Questions: Demonstrations and Protests against Soviet Aggression in Hungary’], letter from Paul L. Tomori to Salazar, January 1958.
} 
state situated behind the Iron Curtain informed the response of many nations (for more on the hesitation and failures of Western states see Hellema 1995). Even Canada, which ended up taking in a large number of refugees relative to its size, hesitated in the early stages of the crisis to assist Hungarians fleeing from the violence of the Revolution and its aftermath (see Donaghy 2010). For the Portuguese government, the Hungarian Revolution and the refugee crisis that followed in its wake proved difficult to navigate politically and ideologically. Though the Portuguese government wanted to project an image of the Portuguese people as co-martyrs in a broader civilizational struggle against the violence, barbarism, and immorality of communism, the Salazar regime ultimately had more in common with the oppressors than with the people who stood and died in opposition to Hungary's state socialist regime and its Soviet backers. In the end, the discourse of martyrdom that Salazar's propagandists employed was a dangerous if politically and ideologically expedient narrative, and thus speaks volumes to the potential for social and political destabilization that the Hungarian Revolution embodied and had the potential to provoke well beyond the boundaries of communist Eastern Europe.

\section{Works Cited}

\section{Archival Sources}

Arquivo Nacional Torre do Tombo (Portuguese National Archives), AOS/CO/NE-21, Pt. 14, "Correspondência sobre as seguintes questões: Política externa da Hungria" ['Correspondence Concerning the Following Questions: The Foreign Politics of Hungary'].

—. AOS/CO/PC-46, Pt. 13, "Correspondência sobre as seguintes questões: Manifestações e protestos contra a agressão soviética à Hungria" ['Correspondence Concerning the Following Questions: Demonstrations and Protests against Soviet Aggression in Hungary'].

. AOS/CO/NE-25, Pt. 2, "Correspondência sobre as seguintes questões: Pedido de concessão de asilo politico em Portugal para refugiados húngaros" ['Correspondence Concerning the Following Questions: Petitions for the Granting of Political Asylum in Portugal by Hungarian Refugees'].

\section{Other Primary Sources}

Conselho Nacional Húngaro ['Hungarian National Council']. 1951. "Protestai Contra as Deportações em Massa dos Húngaros!" ['Protest Against the Mass Deportations of Hungarians']. Lisbon: N.p.

Edelsheim Gyulai, Ilona. 2005. The Memoirs of Countess Ilona Edelsheim Gyulai, Widow of Stephen Horthy, Vice-Regent of Hungary. London: Purple Pagoda Press. Horthy, Miklós. 2000. Admiral Nicholas Horthy: Memoirs. Annotated by Andrew L. Simon. Safety Harbor, FL: Simon Publications.

Horthy Miklosné. 2015. Napló 1944-45 ['Diary 1944-45']. Budapest: Libri.

N.a. 1956. "Os trabalhadores Portuguese concentrar-se-ão no Terreiro do Paço em 7 de

Dezembro para uma pública mnifestação contra o vil atentado à liberdade do povo húngaro" ['Portuguese Workers to Gather in the Terreiro do Paço on December 7 for a Public Demonstration Against the Vile Attacks on the Liberty of the Hungarian People'], Diário de Manhã. November 27. 
Jobbitt, Steven. "Hungarian Martyrs, Refugees, and the Politics of Anticommunism in Salazar's Portugal, 1956-

1957." Hungarian Cultural Studies. e-Journal of the American Hungarian Educators Association, Volume 9 (2016) DOI: $10.5195 /$ ahea.2016.263

North Atlantic Council (NATO). 1957. "Report on Hungarian Refugees." April 17. http://www.nato.int/nato_static/assets/pdf/pdf_archives_hungarian_revolution/20130904_ C-M_57_65-ENG.PDF

RTL. 2007. "Horthy menyének különös emlékei: A grófnő részletes beszámolója a kormányzó családjának számüzetéséről” [‘The Unusual Remembrances of Horthy’s Daughter-in-Law: The Countesses's Detailed Account of the Exile of the Regent's Family']. http://rtl.hu/rtlklub/hirek/hatter/cikkek/107077

United Nations General Assembly. 1956. "Interim Report by the Secretary-General on Refugees from Hungary." UN doc. A/3371. November 19. http://www.un.org/en/ga/search/view_doc.asp?symbol=A/3371

Valadão, Ramiro. 1956. "Hungria Mártir" ['Martyred Hungary']. Lisbon: N.p.

Secondary Sources

Colville, Rupert. 2006. "A Matter of the Heart: How the Hungarian Crisis Changed the World of Refugees." Refugees. 144/3: 4-23.

Donaghy, Greg. 2010. “'An Unselfish Interest?': Canada and the Hungarian Revolution, 1954-1957." In The 1956 Hungarian Revolution: Hungarian and Canadian Perspectives. Eds. Christopher Adam, Tibor Egervari, Leslie Lacko, and Judy Young. Ottawa: The University of Ottawa Press: 256-274.

Fogarassy, Miklós. 2009. "Egy régi iskoláról: Emlékezés a győri bencés gimnáziumról" ['About an Old School: Memories of the Benedictine College in Györ']. http://vigilia.hu/regihonlap/2009/11/fogarassy.htm

Gómez, Hipólito de la Torre. 2010. O Estado Novo de Salazar ['Salazar's New State']. Alfragide: Texto.

Gosztonyi, Péter. 1973. Miklós von Horthy: Admiral und Reichsverweser ['Miklós von Horthy: Admiral and Regent']. Göttingen: Musterschmidt.

—. 1992. A kormányzó Horthy Miklós és az emigrázió. Budapest: Százszorszép.

Judt, Tony. 2005. Postwar: A History of Europe Since 1945. New York: Penguin.

Hellema, Duco. 1995. "The Relevance and Irrelevance of Dutch Anti-Communism: The Netherlands and the Hungarian Revolution, 1956-57." Journal of Contemporary History 30/1 (January): 169-186.

Hidas, Peter I. 1998. "The Hungarian Refugee Student Movement of 1956-57 and Canada." Canadian Ethnic Studies/Etudes ethniques au Canada. 30: 19-49.

Holburn, Louise W., Philip Chartrand, and Rita Chartrand. 1975. Refugees, a Problem of Our Time: The Work of the United Nations High Commissioner for Refugees, 1951-1972. Metuchen, N.J.: Scarecrow Press.

Lewis, Paul H. 2002. Latin Fascist Elites: The Mussolini, Franco, and Salazar Regimes. Westport, CT: Praeger.

Mailer, Phil. 1977. Portugal: The Impossible Revolution? London: Solidarity.

Mazower, Mark. 2000. Dark Continent: Europe's Twentieth Century. New York: Vintage Books.

Neto, Manuel Teles. 2006. Retalhes do Massacre de Batepá ['Scraps of the Massacre of Batepá']. Luanda: União dos Escritores Angolanos. 
Nóvé, Béla. 2013. "The Orphans of the Revolution: Hungarian Under-age Refugees of 1956." In East Central Europe in Exile, Volume One: Transatlantic Migrations. Ed. Anna Mazurkiewicz. Newcastle upon Tyne: Cambridge Scholars Publishing: 65-92.

Pais de Sousa, Jorge. 2012. O Fascismo Catedrático de Salazar ['The Professorial Fascism of Salazar']. Coimbra: Imprensa da Universidade de Coimbra.

Payne, Stanley. 1995. A History of Fascism, 1914-1945. Madison: The University of Wisconsin Press.

Pittaway, Mark. 2012. The Worker's State: Industrial Labor and the Making of Socialist Hungary, 1944-1958. Pittsburgh: Pittsburgh UP.

Raby, D.L. 1988. Fascism and Resistance in Portugal: Communists, Liberals and Military Dissidents in the Opposition to Salazar, 1941-1974. Manchester: Manchester UP.

Rainer, János M. 2010. "The Hungarian Revolution of 1956: Causes, Aims, and Course of Events." In The 1956 Hungarian Revolution: Hungarian and Canadian Perspectives. Eds. Christopher Adam, Tibor Egervari, Leslie Lacko, and Judy Young. Ottawa: The University of Ottawa Press: 12-31.

Sakmyster, Thomas. 1994. Hungary's Admiral on Horseback: Miklós Horthy, 1918-1944. Boulder: East European Monographs/New York: Columbia UP.

Sauerwein, Júlio. 1955. Exiliados Régios no Estoril: Quem São, Como Vivem e Pensam, $o$ Que Esperam ['Exiled Royalty in Estoril: Who Are They, How Do They Live and Think, and What Are They Waiting For?']. Lisbon : Parceria A.M. Pereira.

Solsten, Eric, ed. 1993. Portugal: A Country Study. Washington: GPO for the Library of Congress.

Szalai, Béla. 2012. "Pannonhalma az 1956-os forradalom idejében" ['Pannonhalma at the Time of the 1956 Revolution']. http://pannonhalma70-

74.gportal.hu/portal/pannonhalma70-74/upload/251068_1370601938_08667.pdf

Vajnai, Lajos. 1990. "Horthy Lisszabonban" ['Horthy in Lisbon']. História 12/5-6: 36.

Zieck, Marjoleine. 2013. "The 1956 Hungarian Refugee Emergency: An Early and Instructive Case of Resettlement." Amsterdam Law Forum. 5/2: 45-63. 